\title{
PENGARUH ASPEK INVESTASI DAN ASPEK LIKUIDITAS TERHADAP KEPUTUSAN KEBIJAKAN DEVIDEN
}

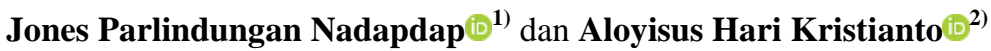 \\ ${ }^{1,2}$ Manajemen, Institut Shanti Bhuana \\ 1,2 J1 Bukit Karmel no 1, Bengkayang, Kalimantan Barat, 79211 \\ E-mail : jones.parlindungan@ @ shantibhuana.ac.id ${ }^{1)}$, aloysius.hari@ shantibhuana.ac.id ${ }^{2)}$
}

\begin{abstract}
ABSTRAK
Penelitian ini bertujuan untuk mengetahui pengaruh aspek investasi dan aspek likuiditas terhadap keputusan kebijakan dividen. Variabel investasi perusahaan yang dipergunakan sebagai parameter adalah asset growth dan aspek likuiditas mempergunakan parameter current ratio. Kemampuan perusahaan dalam mengelola kebutuhan dana yang didapatkan dari pasar modal melalui investasi yang dilakukan para pemilik saham atau investor. Perbedaan cara atau karakter perusahaan yang sudah mapan atau berkembang pesat dengan perusahaan yang baru berkembang dalam mengalokasikan dana terhadap aktivitas operasional sebagai suatu fenomena yang menarik untuk dilakukan penelitian. Analisis yang dipergunakan adalah analisis deskriptif kuantitatif. Alat analisis yang digunakan adalah regresi data panel software Eviews 9. Jumlah data sampel yang dipergunakan adalah 21 perusahaan yang masuk kategori LQ45 pada laporan agustus 2019 (periode 2015 2019), perusahaan atau emiten yang membagikan dividen selama 3 tahun berturut-turut dan perusahaan diluar perbankan dan infrastruktur karena keterbatasan kategori asset pada saat melakukan pengukuran asset growth. Hasil penelitian menunjukkan bahwa variabel asset growth berpengaruh positif dan signifikan terhadap dividend pay-out ratio, dan variabel current ratio memiliki pengaruh positif dan signifikan terhadap dividend pay-out ratio.
\end{abstract}

Keywords: Keputusan, Kebijakan Dividen, Aspek Likuiditas, Aspek Investasi, Pasar Modal.

\section{PENDAHULUAN}

Pasar modal memiliki arti sebagai pasar untuk berbagai instrument keuangan (sekuritas) jangka panjang yang dapat diperjualbelikan, baik berupa hutang maupun modal itu sendiri, baik yang diterbitkan oleh instansi pemerintah, otoritas publik, atau perusahaan swasta (Husnan, 2015). Pasar modal memiliki peranan yang sangat penting dalam mobilisasi ataupun mengumpulkan dana dari masyarakat atau investor dalam mendukung atau menunjang pembangunan nasional. Akses dana yang ada di pasar modal membuat banyak perusahaan nasional maupun perusahaan yang berbentuk patungan dalam mengumpulkan dana dari masyarakat dengan tujuan yang beragam. Tujuan utama yang dilakukan adalah meningkatkan produktivitas kerja perusahaan melalui ekspansi usaha dan/atau pembenahan struktur modal perusahaan dalam meningkatkan daya saing.

Saham merupakan salah satu produk yang ada pada aktivitas pasar modal, selisih atas bergeraknya harga saham dapat membuat investor mendapatkan keuntungan atau pendapatan atau return. Return yang diperoleh investor atas dana atau modal yang di investasi pada saham dalam bentuk laba atau umumnya disebut sebagai dividen ataupun selisih harga jual saham dengan harga beli saham atau umumnya disebut sebagai capital gain. Harga saham dapat didefinisikan sebagai harga yang terjadi di bursa pada periode tertentu (Darmadji \& Fakhrudin, 2012). Harga saham yang terjadi bisa mengalami perubahan naik atau mengalami penurunan harga dalam rentang waktu yang cukup cepat. Perubahan harga saham dapat berubah dalam hitungan menit bahkan dapat berubah dalam hitungan jam atau menit atau bahkan dalam hitungan detik. fluktuasi tersebut disebabkan karena aktivitas antara permintaan dengan penawaran dan antara pembeli saham dengan penjual saham pada pasar modal.

Pada umumnya investor berusaha untuk meningkatkan kekayaannya dengan mengantisipasi keuntungan berupa Dividen dan capital gain. Di sisi lain, perusahaan mengantisipasi ekspansi lanjutan dalam operasi operasionalnya, yang dapat segera menghasilkan lebih banyak profitabilitas. Kebijakan dividen sangat penting bagi pemegang saham karena memastikan bahwa dividen dibayarkan sesuai dengan harapan mereka. Investor yang menghindari risiko (Risk Aversion) percaya bahwa semakin besar jumlah keuntungan yang diharapkan atau diprediksi atas hasil atau pengembalian risiko, semakin besar risikonya. Dividen yang diperoleh sekarang akan bernilai lebih dari keuntungan modal yang diperoleh di masa depan. Akibatnya, investor nonspekulatif akan lebih memilih dividen daripada capital gain.

Investor pada saat melakukan investasi di pasar modal selalu melakukan beberapa pertimbangan, investor juga memerlukan informasi yang akurat untuk memastikan sejauh mana keterkaitan antara variabelvariabel yang menyebabkan harga fluktuatif terhadap harga saham suatu perusahaan yang akan 
dipertimbangkan untuk dibeli. Apabila pengaruh variabel-variabel tersebut sudah diketahui atau di identifikasi, maka investor memilih strategi yang tepat dalam memilih perusahaan sebagai tempat untuk menanamkan modal.

Memaksimalkan harga saham dalam pemenuhan kebutuhan dana perusahaan dapat dilakukan dengan cara pengeluaran yang berasal dari laba ditahan atau laba perusahaan dan penyusutan, sedangkan penjualan saham merupakan salah satu pengeluaran eksternal. Aktivitas pengeluaran eksternal ini, perusahaan wajib memiliki suatu kebijakan yang berkaitan aktivitas dividen. Kebijakan dividen para pemegang saham didefinisikan sebagai keputusan apakah laba yang diperoleh perusahaan harus dibagikan sebagai dividen atau disimpan sebagai laba ditahan untuk tujuan membiayai pengeluaran tambahan di masa depan.

Pemegang saham adalah orang yang membeli saham pada perusahaan efek atau perusahaan yang tercatat di bursa efek. Idealnya, lebih banyak saham yang dimiliki harus dimiliki oleh masyarakat umum (Sesa, 2020). Tujuannya adalah untuk mengendalikan kebijakan dan operasi perusahaan dengan lebih baik dan sesuai dengan keinginan pemegang saham. Pernyataan tersebut lebih sering terjadi pada perusahaan-perusahaan di Amerika, dimana perusahaan lebih banyak menjual sahamnya ke publik sehingga konflik kepentingan yang terjadi sangat kecil. Hal ini dikarenakan adanya perwakilan dari pemegang saham dalam perusahaan yang bersifat independen sehingga ada fungsi pengawasan yang dijalankan (Yosefa, Sentosa and Sarpan, 2020).

Kepentingan pemilik lebih dominan dalam hal kebijakan dividen dan investasi perusahaan dalam hal ekspansi (Jati, 2020). Tidak adanya kepercayaan pemegang saham minoritas dalam perusahaan mengakibatkan ketidakpercayaan manajer dalam membuat kebijakan terkait kesejahteraan pemegang saham minoritas dalam jangka pendek yaitu capital gain dan dalam jangka panjang berupa dividen atas saham yang dimiliki.

Ini adalah paradigma yang menggambarkan dan memecahkan masalah dalam hubungan antara pemilik bisnis dan agen mereka. Pemegang saham dan eksekutif perusahaan sering memiliki hubungan seperti ini sebagai prinsipal dan agen. Agen ada dalam berbagai jenis hubungan bisnis, apakah itu antara pembeli dan penjual atau pengecer dan pelanggan. Prinsipal atau prinsipal telah menyewa agen untuk memberikan layanan atas nama mereka (Asmirantho and Yuliawati, 2015).

Ketika investor tidak setuju, biasanya karena mereka memiliki tujuan yang berbeda atau penghindaran risiko. Teori keagenan berkaitan dengan tidak sepakat semacam ini. Eksekutif perusahaan, misalnya, mungkin berusaha memperluas operasi mereka ke segmen pasar baru yang risiko, semuanya dengan harapan meningkatkan keuntungan perusahaan dan kompensasi jangka pendek. Bagi pemegang saham yang terutama peduli dengan pertumbuhan pendapatan jangka panjang dan kenaikan harga saham, ini dapat memberikan risiko yang tidak dapat dibenarkan (Ningrum, 2019).

Perusahaan yang berkembang pesat harus lebih mengandalkan modal eksternal. Selain itu, biaya pengembangan untuk penjualan saham biasa lebih besar daripada biaya penerbitan surat utang yang mendorong perusahaan untuk lebih mengandalkan utang. Namun, pada saat yang sama perusahaan yang berkembang pesat sering menghadapi ketidakpastian yang lebih besar, yang cenderung mengurangi keinginan mereka untuk menggunakan utang.

Literatur penelitian terdahulu yang berkaitan dengan variabel asset growth dan current ratio yang mempengaruhi dividend pay-out ratio yaitu: penelitian (Febrianti dan Djumahir, 2014) dengan judul "Analisis Pengaruh Return On Asset, Debt To Equity Ratio, Firm Size, Current Ratio, dan Growth Terhadap Pembayaran Dividen Pada Perusahaan Manufaktur Yang Terdaftar di Bursa Efek Indonesia Tahun 2009-2012". Hasil penelitian tersebut menunjukkan hasil bahwa variabel Current Ratio dan Growth memiliki pengaruh signifikan dan berhubungan positif terhadap kebijakan pembayaran Dividend Pay-out Ratio (DPR). Sebaliknya (Rezeki dan Widyarti, 2011) melakukan penelitian yang berjudul Pengaruh DER, NPM, AG, FS, dan CR terhadap DPR. (Studi Kasus Pada Perusahaan Non Financial yang Terdaftar di BEI Periode 2005-2009), hasil penelitian tersebut menunjukkan Asset Growth dan Current Ratio berpengaruh negative dan tidak signifikan terhadap Dividend Pay-out Ratio.

Kebijakan dividen dipengaruhi faktor internal diantaranya posisi likuiditas perusahaan, Kebutuhan dana untuk membayar utang, tingkat perumbuhan perusahaan, pengawasan Terhadap perusahaan (Riyanto, 2010). Perusahaan dengan perkembangan pesat membutuhkan dana lebih untuk melakukan investasi. Kebutuhan pendanaan dipenuhi terlebih dahulu dari ekuitas internal, karena banyak dana yang dialokasikan ke laba ditahan, yang menyebabkan laba untuk membayar dividen berkurang. Terutama dari laba ditahan, persentase pendapatan (laba) yang akan digunakan untuk investasi sebagai laba ditahan lebih besar daripada persentase laba yang akan dibagikan sebagai dividen.

Kedua aspek ini selalu bertentangan jika perusahaan membayar dividen, yang cenderung menaikkan harga saham karena investor tertarik dengan jumlah dividen yang dibagikan. Kenaikan harga saham berarti meningkatkan nilai perusahaan. Namun, pembayaran dividen yang lebih besar akan mengurangi laba ditahan dan selanjutnya mengurangi total sumber dana internal, akibatnya mengurangi kemampuan perusahaan untuk berinvestasi sehingga akan menurunkan tingkat pertumbuhan perusahaan dan hal ini juga akan berdampak pada harga saham di perusahaan. berupa penurunan harga saham. Saham menuntut perusahaan untuk menyeimbangkan kebutuhan dana internal dan keinginan pemegang saham. Perusahaan 
dengan pendapatan dan arus kas yang fluktuatif enggan berkomitmen untuk meningkatkan dividen setiap tahun.

Peneliti tertarik untuk menguji fenomena dari dua aspek yang saling bertentangan dengan kebijakan dividen dan penelitian-penelitian terdahulu yang sudah pernah dilakukan, sehingga peneliti melakukan penelitian terhadap variabel asset growth dan current ratio terhadap dividend pay-out ratio pada perusahaan yang terdaftar pada LQ45.

\section{RUANG LINGKUP}

Ruang lingkup dalam penelitian ini mencakup:

1. Kebijakan dividen yang dilakukan perusahaan lebih difokuskan kepada dividend pay-out ratio

2. Likuiditas untuk melihat baik atau tidaknya kinerja perusahaan dalam mengumpulkan dana dari masyarakat

3. Investasi yang terjadi pada perusahaan menggunakan asset growth, untuk melihat peningkatan aset yang ada pada perusahaan untuk aktivitas operasional perusahaan.

\section{BAHAN DAN METODE}

Pada bagian ini menggunakan kajian teoretis satu variabel atau lebih antara variabel bebas (independent variable) yaitu investasi dengan menggunakan parameter asset growth dan likuiditas dengan parameter current ratio terhadap variabel terikat (dependent variable), adapun kajian teoretis pada penelitian ini adalah:

\subsection{Investasi}

Dalam memilih investasi yang menghasilkan keuntungan (return), investor memerlukan berbagai informasi sebagai landasan keputusan. Analisis investasi saham merupakan hal yang mendasar untuk diketahui investor karena tanpa adanya analisis yang baik dan rasional maka investor akan mengalami kerugian. Analisis investasi saham dapat dibedakan menjadi dua pendekatan yaitu analisis teknikal dan analisis fundamental. Analisis teknikal merupakan upaya untuk memperkirakan harga saham dengan mengamati perubahan harga saham tersebut di waktu yang lalu, analisis teknikal tidak memperhatikan faktor-faktor fundamental (Husnan, 2015), sedangkan analisis fundamental memperkirakan harga saham di masa yang akan datang dengan mengestimasi nilai faktor-faktor fundamental yang mempengaruhi harga saham di masa yang akan datang dan menerapkan hubungan variabelvariabel tersebut sehingga diperoleh taksiran harga saham (Husnan, 2015).

\subsection{Likuiditas}

Likuiditas merupakan kemampuan suatu perusahaan dalam memenuhi aktivitas perusahaan dalam hal kewajiban, dan juga digunakan dalam menunjukkan posisi keuangan atau posisi kekayaan dari suatu perusahaan. Penilaian kinerja perusahaan menggunakan analisis fundamental seperti analisis rasio keuangan, dimana di dalamnya terdapat rasio likuiditas.

Rendahnya likuiditas menjadi salah satu indikasi atau tanda dimana suatu perusahaan berada pada ambang kebangkrutan. Apabila tingkat likuiditas yang dimiliki suatu perusahaan tinggi, maka kinerja perusahaan akan semakin baik. Begitu juga sebaliknya, jika tingkat likuiditas yang dimiliki perusahaan rendah, maka kinerja perusahaan akan dinilai buruk. Tingkat likuiditas yang dimiliki perusahaan tinggi, maka suatu perusahaan bisa lebih mudah mendapatkan atau mengumpulkan dana dari masyarakat melalui pasar modal atau mendapatkan dukungan dari berbagai pihak misalnya lembaga keuangan, kreditur, dan supplier.

Pengertian likuiditas jika dilihat dari aspek utang, Likuiditas adalah nilai yang memiliki fungsi untuk mengukur kemampuan perusahaan dalam proses pelunasan utang-utangnya. Pengertian utang yang dijelaskan sebelumnya dalam likuiditas merupakan utang yang bersifat jangka pendek. Utang jangka pendek merupakan salah satu dan atau berbagai macam utang yang harus dibayar dalam waktu dekat atau memiliki jangka waktu yang kurang dari satu tahun. Jika nilai likuiditas nya perusahaan tinggi, berarti perusahaan tersebut mampu membayar utangnya. Sebaliknya, jika tingkat likuiditas perusahaan rendah, berarti perusahaan mengalami kesulitan dalam melunasi utangnya. Salah satu penyebabnya karena utang akan dibayar dengan ketersediaan kas yang dimiliki perusahaan tidak mencukupi.

Perusahaan perlu memiliki jumlah ketersediaan kas yang cukup untuk segala aktivitas operasional dan keperluan lainnya. Likuiditas merupakan nilai yang bukan sekadar "nilai" karena likuiditas menjadi patokan perusahaan dalam mencari solusi ketika diketahui ada masalah dalam proses pembayaran utang kepada kreditur. Jika ketersediaan kas yang dimiliki oleh perusahaan tidak cukup dalam membayar utang atau liabilitas atau kewajiban jangka pendek, maka akan berdampak atau akan mempengaruhi aktivitas operasional bisnis perusahaan. Apalagi aktivitas operasional perusahaan harus terus berjalan supaya perusahaan memperoleh keuntungan atau pendapatan.

Kesempatan investasi atau Investment Opportunity Set (IOS) menggambarkan tentang luasnya kesempatan atau peluang investasi bagi suatu perusahaan (Hartono, 2016:48). Investment Opportunity Set (IOS) menunjukkan kemampuan perusahaan memperoleh keuntungan dari prospek pertumbuhan. Pertumbuhan perusahaan merupakan suatu harapan penting yang diinginkan oleh pihak internal perusahaan yaitu manajemen maupun eksternal perusahaan seperti investor dan kreditur. Pertumbuhan diharapkan dapat memberikan aspek yang positif bagi perusahaan sehingga meningkatkan kesempatan berinvestasi di perusahaan tersebut. Bagi investor pertumbuhan perusahaan merupakan suatu prospek yang menguntungkan, karena investasi yang ditanamkan 
diharapkan akan memberikan return yang tinggi di masa yang akan datang. Perusahaan yang tumbuh akan di respons pasar dan peluang pertumbuhan terlihat pada peluang investasi yang diproksikan dengan berbagai macam kombinasi nilai investment opportunity set.

Penelitian terdahulu pada variabel ini adalah penelitian yang dilakukan (Gean Karlos Purba, 2019) dimana Current ratio (CR) berpengaruh negatif dan tidak signifikan terhadap kebijakan dividen pada sub sektor farmasi dan kosmetik periode 2012-2016 dan hasil penelitian yang dilakukan oleh (Afrina dan Triyonowati, 2014) menunjukkan bahwa current ratio memiliki pengaruh positif dan signifikan terhadap dividend payout ratio.

\subsection{Dividend Pay-out Ratio}

Dividend Pay-out Ratio adalah besarnya persentase laba bersih yang dimiliki perusahaan setelah pajak yang dibagikan dalam bentuk dividen kepada para pemegang saham (Sudana, 2011). Dividen yang dibagikan biasanya dilakukan dalam periode waktu tertentu. Bisa setahun sekali atau dua kali tergantung kebijakan perusahaan. Aktivitas dunia investasi, ada berbagai parameter atau beberapa rasio-rasio dan metrik yang dapat digunakan oleh para investor atau para pemilik modal dalam melakukan penilaian seberapa menguntungkan suatu portofolio. Parameter pertama adalah capital gain, yaitu jumlah atau tingkat keuntungan yang didapatkan dari hasil selisih harga saham. Parameter kedua adalah dividen atau hasil keuntungan dari pembagian laba perusahaan.

Dividend Pay-out Ratio merupakan persentase dari pendapatan yang diberikan oleh suatu perusahaan atau emiten kepada para pemilik atau pemegang saham. Laba ditahan atau setiap uang yang tidak dibayarkan kepada pemegang saham biasanya digunakan atau dimanfaatkan untuk membayar utang atau berinvestasi kembali dalam beberapa aktivitas operasional penting perusahaan. sehingga dividend pay-out ratio saja tidak cukup digunakan sebagai patokan seberapa baik kesehatan suatu perusahaan atau emiten yang terdaftar di bursa. Meski demikian, dividend pay-out ratio bisa menjadi salah satu indikasi seberapa banyak perusahaan memberikan keuntungan kepada pemegang saham. Begitu juga, seberapa banyak jumlah pendapatan disimpan oleh perusahaan untuk di investasi kembali untuk peningkatan pertumbuhan perusahaan, pelunasan hutang, atau sebagai simpanan kas.

Umumnya perusahaan rintisan yang baru berkembang umumnya akan menahan lebih banyak laba untuk kepentingan pendanaan dan pertumbuhan perusahaan. kebijakan ini dilakukan supaya dapat memberikan hasil dividen yang lebih menguntungkan pada masa depan, sehingga dividen yang diberikan saat ini menjadi lebih kecil. Begitu sebaliknya perusahaan yang lebih matang dan sudah berkembang umumnya akan membagikan dividen dengan nilai yang lebih tinggi karena tidak pada suatu titik tidak ada ruang untuk membuat pertumbuhan baru atau jenuh. Oleh karena hal tersebut alasan membayar dividen menjadi langkah penggunaan laba yang lebih baik.

Investor yang tertarik dalam melakukan aktivitas investasi jangka panjang umumnya akan memilih perusahaan yang memiliki Dividend Pay-out Ratio rendah karena investor umumnya lebih tertarik dengan pertumbuhan modal. Sebaliknya, karakter investor jangka pendek akan lebih menyukai perusahaan dengan nilai Dividend Pay-out Ratio tinggi karena hasil yang didapatkan juga lebih tinggi. Pembagian dividen biasanya dilakukan pada saat perusahaan berhasil memperoleh laba bersih. sebaliknya, apabila setelah tutup tahun buku tidak ada keuntungan atau laba atau bahkan mengalami kerugian, umumnya perusahaan tidak akan membagikan dividen. Perlu diperhatikan juga bahwa dividend pay-out ratio tidak boleh terlalu tinggi diberikan oleh perusahaan karena pada dasarnya dividen dibayar tunai sehingga nilai yang terlalu tinggi bisa mengganggu kondisi likuiditas perusahaan dan menyulitkan pengelolaan kas.

\section{PEMBAHASAN}

Menurut (Creswell, 2014), penelitian kuantitatif adalah sarana untuk mengevaluasi hipotesis objektif dengan cara menguji hubungan antar variabel yang mungkin diukur pada instrumen sehingga data yang diberi nomor dapat diperiksa dengan menggunakan prosedur statistik. Populasi penelitian ini adalah perusahaan yang termasuk dalam laporan LQ45 20152019. Pendekatan non-probability sampling dan metode sampel purposive digunakan dalam penelitian ini. Perusahaan yang dipilih untuk penelitian ini adalah perusahaan yang telah membagikan dividen selama tiga tahun berturut-turut, serta perusahaan yang tidak bergerak di bidang konstruksi atau perbankan. Ada total 21 perusahaan yang memenuhi dua persyaratan ini dan diperoleh antara tahun 2015 dan 2017.

Model analisis yang digunakan pada penelitian ini dapat dilihat pada gambar 1 .

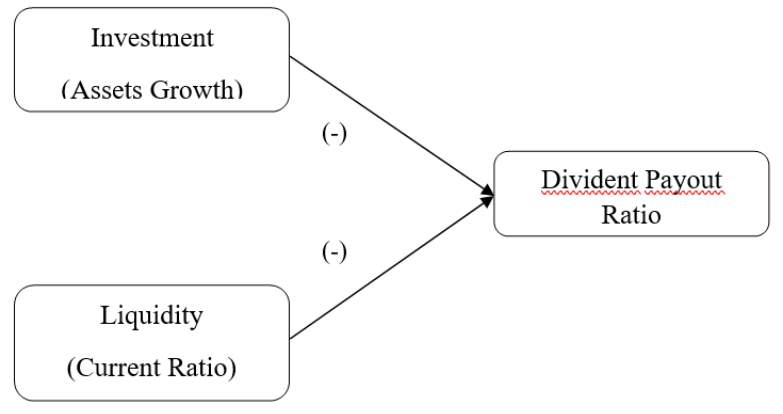

Gambar 1. Model Analisis 
Pada gambar 1 menggambarkan model analisis yang digunakan oleh peneliti dan Variabel yang digunakan dalam penelitian ini adalah:

1. Pertumbuhan Aset, adalah perubahan tahunan (tingkat pertumbuhan) dari total aset (Jogiyanto, 2013). Ini dihitung sebagai persentase perubahan Aset selama periode tertentu. Penentuan variabel pertumbuhan aset dengan menggunakan rumus (1)

Asset growth $=\underline{\text { Total Assets } t-\text { Total Assets } t-1}$

Total Assets $t-1$

2. Likuiditas adalah Rasio yang digunakan untuk mengukur kemampuan perusahaan untuk memenuhi kewajiban jangka pendeknya. Rasio likuiditas digunakan untuk membandingkan kewajiban jangka pendek dengan sumber daya jangka pendek (aktiva lancar) yang tersedia untuk memenuhi kewajiban jangka pendek tersebut. Penentuan variabel likuiditas dengan menggunakan rumus (2).

\section{Current Ratio $=$ Current Asset \\ Current Liabilities}

3. Rasio pembayaran dividen adalah rasio jumlah total dividen yang dibayarkan kepada pemegang saham relatif terhadap laba bersih perusahaan. Ini adalah persentase pendapatan yang dibayarkan kepada pemegang saham melalui dividen. Penentuan variabel dividen dengan menggunakan rumus (3).

Dividend pay-out ratio $=\frac{\text { Dividend per share }}{\text { Earning per share }}$

4. Penelitian ini menggunakan model yang disajikan dengan menggunakan rumus (4),

$\mathrm{DPR}=\mathrm{a}-\mathrm{b} 1$ Asset growth $-\mathrm{b} 2$ Liquidity $+\mathrm{e}$

Berdasarkan kerangka model analisis dan penjelasan variabel, maka hipotesis penelitian adalah sebagai berikut:

Hipotesis 1: Pertumbuhan Aset berpengaruh negatif terhadap rasio pembayaran dividen perusahaan yang terdaftar di LQ45 di Bursa Efek Indonesia.

Hipotesis 2 : Likuiditas berpengaruh negatif terhadap dividend pay-out ratio perusahaan yang terdaftar di LQ45 di Bursa Efek Indonesia.

\subsection{Model Regresi Data Panel}

Penelitian ini menggunakan model regresi data panel berupa data yaitu timer series. Penggunaan regresi data panel memerlukan pemilihan model regresi terbaik antara model common effect, model fixed effect dan model random effect. Pemilihan model dilakukan melalui Chow Test dan Lagrange Multiplier Test. Pengujian data penelitian adalah sebagai berikut:

\section{Tes Chow}

Uji Chow bertujuan untuk menguji dan memilih model terbaik yang digunakan dalam regresi data panel penelitian ini, yaitu antara model common effect dan model fixed effect. Ketentuan nilai penampang Chi kuadrat adalah:

1) Jika nilai Chi square cross section $<0,05$ maka model regresi yang dipilih adalah model fixed effect.

2) Jika nilai Chi square cross section >0,05 maka model regresi yang dipilih adalah model common effect.

Jika model FEM yang dipilih maka langkah pengujian selanjutnya adalah melakukan uji Hausman, namun jika model CEM yang dipilih maka akan dilanjutkan ke uji Lagrange Multiplier. Hasil regresi data panel menggunakan e-views untuk uji chow dapat dilihat pada tabel 1 .

Tabel 1. Hasil Uji Chow

\begin{tabular}{|c|c|c|c|}
\hline \multicolumn{4}{|c|}{ Redundant Fixed Effects Tests } \\
\hline \multicolumn{4}{|l|}{ Equation: Untitled } \\
\hline \multicolumn{4}{|c|}{ Test cross-section fixed effects } \\
\hline Effects Test & Statistic & d.f. & Prob. \\
\hline Cross-section F & 1.063669 & $(20,40)$ & 0.4201 \\
\hline Cross-section Chi-square & 26.867361 & 20 & 0.1390 \\
\hline
\end{tabular}

Berdasarkan tabel 1 hasil uji chow diketahui bahwa nilai Chi-square penampang sebesar 0,1390 yang berarti > 0,05, dengan demikian model yang dipilih adalah Common Effect Model sehingga pengujian dilanjutkan dengan uji Lagrange.

\section{Tes Lagrange}

Uji Pengganda Lagrange dengan eviews ini harus dilakukan jika kita berada dalam dua kondisi saat melakukan regresi data panel. Itu adalah:

1) Uji Chow menunjukkan bahwa metode terbaik adalah Common Effect daripada fixed effect. Maka langkah selanjutnya adalah untuk menentukan apakah Common Effect lebih baik daripada Random Effect, maka diperlukan Lagrange Multiplier Test.

2) Uji Hausman menunjukkan bahwa metode terbaik adalah Random effect daripada Fixed Effect. Maka langkah selanjutnya adalah menentukan apakah Random Effect lebih baik dari Common Effect, maka diperlukan Lagrange Multiplier Test. 
Hasil regresi data panel menggunakan e-views untuk uji Lagrange dapat dilihat pada tabel 2.

Tabel 2. Uji Lagrange

Lagrange Multiplier Tests for Random Effects

Null hypotheses: No effects

Alternative hypotheses: Two-sided (Breusch-Pagan) and onesided

(all others) alternatives

Test Hypothesis

\begin{tabular}{|c|c|c|c|}
\multicolumn{4}{|c|}{ Test Hypothesis } \\
\hline & Cross-section & Time & Both \\
\hline Breusch-Pagan & 0.331774 & 0.018352 & 0.350126 \\
\hline & $\mathbf{( 0 . 5 6 4 6 )}$ & $(0.8922)$ & $(0.5540)$ \\
\hline & & & \\
\hline & -0.575998 & -0.135471 & -0.503084
\end{tabular}

\begin{tabular}{|c|c|c|c|}
\hline Honda & -0.575998 & -0.135471 & -0.503084 \\
\hline & -- & -- & -- \\
\hline & & & \\
\hline King-Wu & -0.575998 & -0.135471 & -0.302836 \\
\hline & -- & -- & -- \\
\hline & & & \\
\hline
\end{tabular}

\begin{tabular}{|l|c|c|c|}
\hline & & & \\
\hline Standardized Honda & -0.299268 & 0.314722 & -4.367020 \\
\hline & -- & $(0.3765)$ &
\end{tabular}

\begin{tabular}{|c|c|c|c|}
\hline & & & -- \\
\hline $\begin{array}{c}\text { Standardized King- } \\
\text { Wu }\end{array}$ & -0.299268 & 0.314722 & -2.753871 \\
\hline & -- & $(0.3765)$ & -- \\
\hline Gourierioux, et al.* & -- & -- & 0.000000 \\
\hline & & & $(>=0.10)$ \\
\hline
\end{tabular}

*Mixed chi-square asymptotic critical values:

\begin{tabular}{|r|r|l|l|}
\hline $1 \%$ & 7.289 & & \\
\hline $5 \%$ & 4.321 & & \\
\hline $10 \%$ & 2.952 & & \\
\hline
\end{tabular}

Nilai Breusch-Pagan pada tabel 2 diperoleh sebesar 0,5646 dimana nilainya lebih dari 0,05 . Jadi Uji Pengganda Lagrange menunjukkan bahwa menerima H0 (Hipotesis Null) yang berarti metode estimasi terbaik adalah Common Effect Model.

\subsection{Uji asumsi klasik}

Pemenuhan uji yang harus dilakukan adalah data penelitian harus memenuhi beberapa uji asumsi klasik, yaitu uji normalitas data, uji heteroskedastisitas dan uji multikolinearitas. Hasil pengujian asumsi klasik penelitian ini adalah sebagai berikut:

1. Uji Multikolinearitas

Hasil olah data untuk uji multikolinearitas pada penelitian ini dapat dilihat pada tabel 3.

Tabel 3. Tabel Uji Multikolinearitas

\begin{tabular}{|c|c|c|}
\hline & GROWTH & CR \\
\hline GROWTH & 1 & -0.01792 \\
\hline CR & -0.01792 & 1 \\
\hline
\end{tabular}

Pada tabel 3 menggunakan kriteria penilaian dimana jika nilainya di bawah 0,8 maka data tersebut bebas dari multikolinearitas, tetapi jika nilainya lebih besar dari 0,8 maka data tersebut bermasalah multikolinearitas. data diatas menunjukkan nilai sebesar $-0,01792$ yang berarti lebih kecil dari 0,8 , sehingga dapat disimpulkan bahwa data ini tidak terjadi multikolinearitas.

2. Uji Heteroskedastisitas

Hasil olah data untuk uji heteroskedastisitas pada penelitian ini dapat dilihat pada tabel 4 .

Tabel 4. Tabel Uji Heteroskedastisitas

Residual Cross-Section Dependence Test

Null hypothesis: No cross-section dependence (correlation) in residuals

Equation: Untitled

Periods included: 3

Cross-sections included: 21

Total panel observations: 63

Note: non-zero cross-section means detected in data

Cross-section means were removed during computation of correlations

\begin{tabular}{|c|r|r|r|}
\hline Test & Statistic & d.f. & Prob. \\
\hline Breusch-Pagan LM & 315.8611 & 210 & 0.0000 \\
\hline Pesaran scaled LM & 4.140796 & & 0.0000 \\
\hline Pesaran CD & 1.538557 & & $\mathbf{0 . 1 2 3 9}$ \\
\hline
\end{tabular}

Hasil uji heteroskedastisitas pada tabel 4 dengan CD Pesaran menunjukkan bahwa nilai probabilitas variabel bebas sebesar 0,1239 lebih besar dari taraf signifikan 0,05, sehingga disimpulkan tidak terjadi heteroskedastisitas. 


\subsection{Hasil Regresi Data Panel dengan Metode Common Effect Model}

Hasil analisis regresi data panel dengan model common effect pada penelitian ini dapat dilihat pada tabel 5.

Tabel 5. Metode Common Effect Model

\begin{tabular}{|c|c|c|c|c|}
\hline \multicolumn{5}{|c|}{ Dependent Variable: DPR } \\
\hline \multicolumn{5}{|c|}{ Method: Panel Least Squares } \\
\hline \multicolumn{5}{|c|}{ Date: $10 / 22 / 21$ Time: $15: 46$} \\
\hline \multicolumn{5}{|c|}{ Sample: 20152017} \\
\hline \multicolumn{5}{|c|}{ Periods included: 3} \\
\hline \multicolumn{5}{|c|}{ Cross-sections included: 21} \\
\hline \multicolumn{5}{|c|}{ Total panel (balanced) observations: 63} \\
\hline Variable & Coefficient & \begin{tabular}{|r|} 
Std. \\
Error \\
\end{tabular} & $\mathrm{t}-$ Statistic & Prob. \\
\hline $\mathbf{C}$ & -1.349381 & 0.619796 & -2.177138 & 0.0334 \\
\hline GROWTH & 5.126182 & 2.455977 & 2.087227 & 0.0411 \\
\hline CR & 0.007629 & 0.002166 & 3.521846 & 0.0008 \\
\hline R-squared & 0.215704 & \multicolumn{2}{|c|}{ Mean dependent var } & 0.882043 \\
\hline \begin{tabular}{|c|}
$\begin{array}{c}\text { Adjusted R- } \\
\text { squared }\end{array}$ \\
\end{tabular} & 0.189561 & \multicolumn{2}{|c|}{ S.D. dependent var } & 2.512779 \\
\hline \begin{tabular}{|c|} 
S.E. of \\
regression
\end{tabular} & 2.262114 & \multicolumn{2}{|c|}{ Akaike info criterion } & 4.516925 \\
\hline $\begin{array}{c}\begin{array}{c}\text { Sum squared } \\
\text { resid }\end{array} \\
\end{array}$ & 307.0297 & \multicolumn{2}{|c|}{ Schwarz criterion } & 4.618979 \\
\hline \begin{tabular}{|c|} 
Log \\
likelihood
\end{tabular} & -139.2831 & \multicolumn{2}{|c|}{ Hannan-Quinn criter. } & 4.557063 \\
\hline F-statistic & 8.250868 & \multicolumn{2}{|c|}{ Durbin-Watson stat } & 1.592737 \\
\hline $\begin{array}{l}\text { Prob(F- } \\
\text { statistic) }\end{array}$ & 0.000683 & & & \\
\hline
\end{tabular}

Analisis yang digunakan untuk mengetahui pengaruh variabel bebas terhadap variabel terikat dilakukan dengan menggunakan regresi data panel dengan model common effect. Variabel yang diuji adalah Dividend Pay-out Ratio, investasi perusahaan diukur dengan pertumbuhan aset dan likuiditas diukur dengan rasio lancar. Hasil regresi diperoleh dengan menggunakan software Eviews 9. Interpretasi hasil dari tabel 5 dengan menggunakan rumus (5) dan (6)

DPR Y = C + Growth + Current Ratio $+\mathrm{e}$

$\mathrm{Y}=-1.349381+5.126182+0.007629+\mathrm{e}$

Hasil persamaan regresi pada penelitian ini dapat disimpulkan sebagai berikut:

1. Konstanta dalam hasil regresi adalah $-1,349381$. Artinya jika nilai pertumbuhan aset dan rasio lancar sama dengan 0 maka nilai DPR adalah -1,349381.

2. Hasil Koefisien regresi pertumbuhan aset adalah 5,126182 , nilai ini berarti jika terjadi perubahan pertumbuhan aset sebesar satu persen dengan asumsi variabel lain konstan maka inflasi dapat mengakibatkan perubahan DPR sebesar 5,126182 atau setiap kenaikan Rp. 1 DPR dipengaruhi oleh pertumbuhan aset sebesar 5.126182.

3. Koefisien regresi current ratio sebesar 0,007629 yang artinya apabila terjadi perubahan current ratio sebesar satu persen dan di asumsi variabel lainnya konstan maka dapat mengakibatkan perubahan DPR sebesar 0,007629 dan mempunyai hubungan searah dengan DPR, artinya jika nilai current ratio meningkat maka DPR juga akan meningkat.

\subsection{Uji Parsial atau Uji T}

Pengujian secara parsial bertujuan untuk melihat signifikansi pengaruh variabel antara masing-masing variabel bebas terhadap variabel terikat. Hasil tes untuk uji parsial atau uji $\mathrm{T}$ pada penelitian ini dapat dilihat pada tabel 6 .

Tabel 6. Uji T

\begin{tabular}{|c|c|c|c|c|}
\hline \multicolumn{5}{|c|}{ Dependent Variable: DPR } \\
\hline \multicolumn{5}{|c|}{ Method: Panel Least Squares } \\
\hline \multicolumn{5}{|c|}{ Date: 10/22/21 Time: 15:46 } \\
\hline \multicolumn{5}{|c|}{ Sample: 20152017} \\
\hline \multicolumn{5}{|c|}{ Periods included: 3} \\
\hline \multicolumn{5}{|c|}{ Cross-sections included: 21} \\
\hline \multicolumn{5}{|c|}{ Total panel (balanced) observations: 63} \\
\hline Variable & Coefficient & Std. Error & $\mathrm{t}$-Statistic & Prob. \\
\hline $\mathrm{C}$ & -1.349381 & 0.619796 & -2.177138 & 0.0334 \\
\hline GROWTH & 5.126182 & 2.455977 & 2.087227 & 0.0411 \\
\hline CR & 0.007629 & 0.002166 & 3.521846 & 0.0008 \\
\hline
\end{tabular}

Pengujian variabel individual dilakukan dengan melihat nilai signifikansi masing-masing variabel yang akan diukur yaitu dengan tingkat signifikansi nilai probabilitas $<0,05$ artinya hipotesis awal diterima atau memiliki pengaruh yang signifikan. Jika nilai probabilitas > 0,05 berarti hipotesis awal ditolak atau tidak berpengaruh signifikan.

Berdasarkan data dari tabel 6 diketahui bahwa nilai probabilitas variabel pertumbuhan aset sebesar 0,0411 artinya $<0,05$ sehingga hipotesis awal diterima atau secara parsial variabel pertumbuhan aset berpengaruh positif dan signifikan terhadap dividend pay-out ratio. Untuk variabel current ratio nilai probabilitasnya sebesar 0,0008 atau $<0,05$ hal ini berarti hipotesis awal diterima atau variabel current ratio secara parsial berpengaruh positif dan signifikan terhadap dividend pay-out ratio. 


\subsection{Hasil uji F}

Hasil tes untuk uji F pada penelitian ini dapat dilihat pada tabel 7.

Tabel 7. Uji F

\begin{tabular}{|l|r|c|l|}
\hline R-squared & 0.215704 & $\begin{array}{c}\text { Mean dependent } \\
\text { var }\end{array}$ & 0.882043 \\
\hline $\begin{array}{l}\text { Adjusted } \\
\text { R-squared }\end{array}$ & 0.189561 & $\begin{array}{c}\text { S.D. dependent } \\
\text { var }\end{array}$ & 2.512779 \\
\hline $\begin{array}{l}\text { S.E. of } \\
\text { regression }\end{array}$ & 2.262114 & $\begin{array}{c}\text { Akaike info } \\
\text { criterion }\end{array}$ & 4.516925 \\
\hline $\begin{array}{l}\text { Sum } \\
\text { squared } \\
\text { resid }\end{array}$ & 307.0297 & Schwarz criterion & 4.618979 \\
\hline $\begin{array}{l}\text { Log } \\
\text { likelihood }\end{array}$ & -139.2831 & $\begin{array}{c}\text { Hannan-Quinn } \\
\text { criter. }\end{array}$ & 4.557063 \\
\hline $\begin{array}{l}\text { F-statistic } \\
\text { Prob(F- } \\
\text { statistic) }\end{array}$ & 8.250868 & $\begin{array}{c}\text { Durbin-Watson } \\
\text { stat }\end{array}$ & 1.592737 \\
\hline & $\mathbf{0 . 0 0 0 6 8 3}$ & & \\
\hline
\end{tabular}

Pengujian variabel simultan adalah pengujian yang dilakukan untuk melihat apakah variabel independen secara keseluruhan memiliki pengaruh terhadap variabel independen. Pengujian variabel secara simultan pada tabel 7 dilakukan dengan melihat nilai probabilitas (Fstatistik) dilihat dari hasil regresi menggunakan aplikasi Eviews 9 dengan nilai signifikansi $<0,05$ atau $5 \%$. Jika nilai probabilitas (F-statistik) $<0,05$ berarti terdapat pengaruh keseluruhan yang signifikan dari variabel independen terhadap variabel dependen.

Berdasarkan tabel 7 hasil pengujian variabel independen secara simultan memiliki nilai probabilitas (F-statistik) sebesar 0,0007 atau < 0,05 (5\%) sehingga dapat disimpulkan bahwa asset growth dan current ratio secara simultan berpengaruh terhadap dividend pay-out perbandingan.

\subsection{Koefisien Determinasi $\left(\mathbf{R}^{2}\right)$}

Hasil tes untuk uji determinasi pada penelitian ini dapat dilihat pada tabel 8 .

Tabel 8 Koefisien Determinasi

\begin{tabular}{|l|c|c|c|}
\hline R-squared & $\mathbf{0 . 2 1 5 7 0 4}$ & $\begin{array}{c}\text { Mean dependent } \\
\text { var }\end{array}$ & 0.882043 \\
\hline $\begin{array}{l}\text { Adjusted R- } \\
\text { squared }\end{array}$ & 0.189561 & $\begin{array}{c}\text { S.D. dependent } \\
\text { var }\end{array}$ & 2.512779 \\
\hline $\begin{array}{l}\text { S.E. of } \\
\text { regression }\end{array}$ & 2.262114 & $\begin{array}{c}\text { Akaike info } \\
\text { criterion }\end{array}$ & 4.516925 \\
\hline $\begin{array}{l}\text { Sum squared } \\
\text { resid }\end{array}$ & 307.0297 & $\begin{array}{c}\text { Schwarz } \\
\text { criterion }\end{array}$ & 4.618979 \\
\hline Log likelihood & -139.2831 & $\begin{array}{c}\text { Hannan-Quinn } \\
\text { criter. }\end{array}$ & 4.557063 \\
\hline F-statistic & 8.250868 & $\begin{array}{c}\text { Durbin-Watson } \\
\text { stat }\end{array}$ & 1.592737 \\
\hline Prob(F-statistic) & 0.000683 & & \\
\hline
\end{tabular}

Pengujian menggunakan koefisien determinasi pada tabel 8 bertujuan untuk mengetahui seberapa besar persentase variabel bebas dalam menjelaskan variabel terikat. Nilai koefisien determinasi dapat dilihat dari nilai $R$-squared pada hasil regresi. Berdasarkan data dari tabel 8 diketahui bahwa nilai $R$-squared menunjukkan hasil sebesar 0,2157 atau $22 \%$, hal ini berarti variabel bebas penelitian ini yaitu pertumbuhan aset dan rasio lancar dapat menjelaskan variabel terikat dalam hal ini dividend pay-out ratio sebesar $22 \%$ sedangkan sisanya $78 \%$ dapat dijelaskan oleh variabel lain di luar variabel independen yang digunakan dalam penelitian ini.

Dari hasil pengujian statistik pada penelitian ini dimana Variabel growth berpengaruh positif terhadap dividen pay-out ratio dan signifikan hal ini dikarenakan tingkat pertumbuhan asset yang cepat mengindikasikan adanya ekspansi yang dilakukan oleh perusahaan. Semakin besar ekspansi yang dilakukan oleh perusahaan, semakin besar dana yang dibutuhkan. Hasil ini berbeda dengan penelitian (Ulfa dan Yuniati, 2016) dalam penelitian ini yang menunjukkan bahwa variabel Pertumbuhan Aset berpengaruh negatif dan signifikan terhadap Dividend Pay-out Ratio perusahaan manufaktur di BEI dan penelitian (Lestari, 2019) dimana variabel pertumbuhan aset memiliki berpengaruh negatif dan tidak signifikan terhadap dividend pay-out ratio dan penelitian yang dilakukan (Putri dan Widodo, 2016) pada Perusahaan Pertambangan Bei 2010-2014 dimana variabel asset growth berpengaruh negatif dan tidak signifikan terhadap dividend pay-out ratio.

Variabel current ratio memiliki pengaruh positif dan signifikan terhadap dividend pay-out ratio. Hal ini diduga karena likuiditas yang tinggi oleh perusahaan digunakan untuk membayar dividen kas kepada para pemegang saham dan juga perusahaan yang diteliti ada perusahaan yang terdaftar pada LQ45 dimana perusahaan relatif sudah berkembang secara ukuran bisnis dan aktivitas ekspansi. Penelitian lain yang mendukung dilakukan oleh (Zulkifli, Endri dan Kurniasih, 2017) dimana hasil penelitian nya adalah Temuan empiris ini berarti current ratio semakin tinggi yang disebabkan meningkatnya aset lancar lebih besar dibandingkan dengan peningkatan utang lancar, kemungkinan laba bersih yang dihasilkan perusahaan farmasi lebih besar dialokasikan laba ditahan untuk membiayai aset lancar, maka semakin kecil dividen yang dibayarkan kepada para pemegang saham. Penelitian ini kontra dengan penelitian yang dilakukan oleh (Arsyad, dkk , 2021) dimana pada penelitian tersebut membuktikan bahwa current ratio tidak signifikan bagi dividend pay-out ratio. Ini menunjukkan bahwa teori sinyal tidak dapat diterapkan pada dividen kebijakan dari perspektif likuiditas atau CR. Hasil penelitian tersebut mengasumsikan bahwa jika CR meningkat, nilai DPR akan menurun pada nilai untuk memberikan sinyal yang tidak menguntungkan untuk investor. Sebaliknya, hasil penelitian tersebut masih konsisten dengan sisa dividen tunai dengan asumsi bahwa perusahaan hanya akan 
membayar dividen jika perusahaan memiliki prediksi kepastian bahwa keuntungan berada di ambang batas untuk masa depan kebutuhan investasi sehingga kelebihan pada keuntungan dapat didistribusikan kepada investor di masa depan. Sebaliknya, hasil penelitian tersebut masih konsisten dengan sisa dividen tunai dengan asumsi bahwa perusahaan hanya akan membayar dividen jika perusahaan memiliki prediksi kepastian bahwa keuntungan berada di ambang batas untuk masa depan kebutuhan investasi sehingga kelebihan pada keuntungan dapat didistribusikan kepada investor di masa depan. Dan diperkuat dengan penelitian (Baramuli, 2016) dimana mempunyai current ratio berpengaruh negatif signifikan terhadap dividend pay-out ratio.

\section{KESIMPULAN}

Simpulan dari penelitian yang dilakukan adalah variabel aspek investasi menggunakan parameter asset growth dan aspek likuiditas menggunakan parameter current ratio secara simultan berpengaruh terhadap dividend pay-out ratio dan variabel-variabel aspek investasi menggunakan parameter asset growth dan aspek likuiditas menggunakan parameter current ratio secara parsial berpengaruh terhadap dividend pay-out ratio.

\section{SARAN}

Saran yang dapat diberikan berdasarkan hasil penelitian dan untuk penelitian selanjutnya adalah Penelitian selanjutnya juga dapat memperpanjang periode pengamatan dan menggunakan seluruh populasi di Bursa Efek Indonesia sehingga mewakili perhitungan secara signifikan. Penelitian selanjutnya dapat menambahkan faktor lain yang mungkin menjadi faktor yang mempengaruhi rasio pembayaran dividen seperti rasi probabilitas dimana rasio ini melihat kemampuan perusahaan dalam menghasilkan laba dari pendapatan yang diperoleh dari aktivitas penjualan, aset dan modal saham atau ekuitas. Rasio probabilitas juga digunakan untuk melihat tingkat efisiensi perusahaan dalam menggunakan aktiva perusahaan. Periode dalam penelitian ini menggunakan data time series tahunan sehingga memiliki keterbatasan yaitu jumlah data yang relatif lebih sedikit sehingga untuk penelitian selanjutnya disarankan menggunakan data bulanan atau harian agar hasil analisis lebih detail.

\section{DAFTAR PUSTAKA}

Afrina, T. and Triyonowati (2014) 'Pengaruh Current Ratio, Der dan Roe Terhadap DPR Perusahaan Rokok di BEI', Jurnal ilmu dan Riset Manajemen, 3(9), p. 5.

Arsyad, M. $d k k$. (2021) 'The effect of activity ratios, liquidity, and profitability on the dividend payout ratio', Indonesia Accounting Journal, 3(1), p. 36. doi: 10.32400/iaj.30119.

Asmirantho, E. and Yuliawati, E. (2015) 'Pengaruh
Dividen Per Share (Dps), Dividen Pay-out Ratio (Dpr), Price To Book Value (Pbv), Debt To Equity Ratio (Der), Net Profit Margin (Npm) Dan Return on Asset (Roa)Terhadap Harga Saham Pada Perusahaan Manufaktur Sub Sektor Makanan Dan Minuman Dalam Kema', JIAFE (Jurnal Ilmiah Akuntansi Fakultas Ekonomi), 1(2), pp. 95-117. doi: 10.34204/jiafe.v1i2.525.

Baramuli, N. D. (2016) 'Pengaruh Likuiditas Dan Profitabilitas Terhadap Devidend Pay-out Ratio Pada Top Bank Di Indonesia (Bri, Bank Mandiri, Bni Dan Bca)', Jurnal Berkala Ilmiah Efisiensi, 16(3), pp. 356-366. Available at: https://ejournal.unsrat.ac.id/index.php/jbie/articl e/view/13413/12997.

Creswell, J. W. (2014) Research Design: Qualitative, Quantitative, and Mixed Methods Approaches. Sage.

Darmadji, T dan Fakhruddin. (2012) Pasar Modal Di Indonesia. Edisi. Ketiga. Jakarta: Salemba Empat.

Febrianti, I. and Djumahir (2014) 'Analisis Pengaruh Return On Asset, Debt To Equity Ratio, Firm Size, Current Ratio, Dan Growth Terhadap Pembayaran Dividen Pada Perusahaan Manufaktur Yang Terdaftar Di Bursa Efek Indonesia Tahun 2009-2012', Jurnal Ilmiah Mahasiswa FEB Universitas Brawijaya, 2(1), p. 32. Available at: https://jimfeb.ub.ac.id/index.php/jimfeb/article/ view/834/761.

Gean Karlos Purba, I. F. (2019) 'Pengaruh Kinerja Keuangan Perusahaan Terhadap Devidend Payout Ratio', Jurnal Ekonomi, 24(1), p. 31. doi: 10.24912/je.v1i1.451.

Husnan, Suad. (2015). Dasar-Dasar Teori Portofolio dan Analisis Sekuritas. (Edisi 5). Yogyakarta: UPPN STIM YKPN.

Jati, W. (2020) 'Effect of Current Ratio and Return on Equity on Dividend Pay-out Ratio Policy', Jurnal Ilmiah Ilmu Administrasi Publik, 10(1), p. 63. doi: 10.26858/jiap.v10i1.13571.

Lestari, N. O. (2019) 'Pengaruh Debt Equity Ratio (Der), Return on Asset (Roa), Cash Position (Cash), Asset Growth (Growth) Terhadap Dividen Payout Ratio Pada Perusahaan Manufaktur Sub Sektor Food and Beverage Yang Terdaftar Di Bei Periode 2014-2016', Aplikasi Administrasi: Media Analisa Masalah Administrasi, 22(1), p. 46. doi: 10.30649/aamama.v22i1.112.

Ningrum, N. R. (2019) 'Pengaruh Asset Growth, Dividend Pay-out Ratio (DPR) dan Price Earning Ratio (PER) terhadap Return Saham Pada LQ 45 Di BEI Periode 2015 - 2017', Bisman (Bisnis dan Manajemen): The Journal of Business and Management, 2(2), pp. 94-105. doi: 10.37112/bisman.v2i2.442.

Putri, F. V. and Widodo, A. (2016) 'Pengaruh Roa, Der, 
Dan Ag Terhadap Dpr Perusahaan Pertambangan Bei 2010-2014', Ecodemica, IV(1), pp. 56-62.

Rejeki, S. S. and Widyarti, T. E. (2011) 'Pengaruh Debt To Equity Ratio, Net Profit Margin, Asset Growth, Firm Size, Dan Current Ratio Terhadap Dividend Pay-out Ratio. (Studi Kasus Pada Perusahaan Non Financial Yang Terdaftar Di Bursa Efek Indonesia Periode 2005-2009)'. Available at: http://eprints.undip.ac.id/29255/1/JURNAL_SK RIPSI_SUTARI_SRI_REJEKI_C2A007119.pdf

Riyanto, B. (2010) Dasar-dasar Pembelanjaan Perusahaan, BPFE, Yogyakarta.

Sesa, P. (2020) 'Pengaruh Kandungan Informasi Arus Kas, Dividend Pay-out Ratio Dan Economic Valued Added Terhadap Volume Perdagangan Saham Dengan Size Dan Growth Sebagai Variabel Kontrol', Jurnal Akuntansi Dan Keuangan Daerah, 15(2), pp. 59-75. doi: 10.52062/jakd.v15i2.1625.

Sudana, I. M. (2011) Manajemen Keuangan Perusahaan Teori dan Praktik. Jakarta: Erlangga.

Ulfa, L. M. and Yuniati, T. (2016) 'Jurnal Ilmu dan Riset Manajemen: Volume 5, Nomor 5, Mei 2016
ISSN : 2461-0593 Pengaruh Kinerja Keuangan, Asset Growth Dan Firm Size Terhadap Dividend Pay-out Ratio', Jurnal Ilmu dan Riset Manajemen, 5(5), pp. 1-16.

Yosefa, A., Sentosa, E. and Sarpan, S. (2020) 'Pengaruh Current Ratio, Return on Equity, Dan Dividend Pay-out Ratio Terhadap Price Earning Ratio Pada Perusahaan Sektor Properti Dan Real Estate', Oikonomia: Jurnal Manajemen, 16(1), pp. 1-12. doi: 10.47313/oikonomia.v16i1.998.

Zulkifli, Z., Endri, E. and Kurniasih, A. (2017) 'Determinan Internal Dividend Pay-out Ratio Perusahaan Farmasi Terdaftar Di Bursa Efek Indonesia', Jurnal Keuangan dan Perbankan, 21(2), pp. 238-252. doi: 10.26905/jkdp.v21i2.311. 